та матерів, надання індивідуальної педагогічної та юридичної допомоги, відкритті посад громадської інспекції 3 охорони дитинства й інспекторів охорони дитинства обласного, міського та районного рівня, оновленні нормативно-правової бази та ін.

\title{
Література
}

1. Бєліцька Є. П'ятнадцять років охорони материнства та дитинства на Україні. Київ, 1936. С. 25.

2. В Україні - понад 73 тисячі дітей-сиріт [Електронний ресурс]. Режим доступу: https://health.unian.ua/country/1318291-v-ukrajini-ponad-73-tisyachi-ditey-sirit.html

3. Пащенко В. Ленінське піклування про охорону здоров'я дітей та підлітків. Радянська икола. 1969. № 11. C. 19-20.

4. Соціяльно-правова охорона дитинства та ії завдання : методичний лист. Харків, 1930. С. 1317.

5. Справочник по вопросам охраны детства. Изд. 2, доп. М., 1951. Справочник по вопросам охраны детства. Изд. 2, доп. М., 1951. С. 3 - 5

6. Стинська В. Соціально-педагогічна підтримка материнства й дитинства в Україні (XX початок XXI ст.) : монографія. Івано-Франківськ, 2018. 320 с.

References

1. Bielitska Ye. Piatnadtsiat rokiv okhorony materynstva ta dytynstva na Ukraini. Kyiv, 1936. S. 25.

2. V Ukraini - ponad 73 tysiachi ditei-syrit [Elektronnyi resurs]. Rezhym dostupu: https://health.unian.ua/country/1318291-v-ukrajini-ponad-73-tisyachi-ditey-sirit.html

3. Pashchenko V. Leninske pikluvannia pro okhoronu zdorovia ditei ta pidlitkiv. Radianska shkola. 1969. № 11. S. 19-20.

4. Sotsiialno-pravova okhorona dytynstva ta yii zavdannia : metodychnyi lyst. Kharkiv, 1930. S. 13-17.

5. Spravochnyk po voprosam okhranы detstva. Yzd. 2, dop. M., 1951. Spravochnyk po voprosam okhrand detstva. Yzd. 2, dop. M., 1951. S. 3 - 5

6. Stynska V. Sotsialno-pedahohichna pidtrymka materynstva y dytynstva v Ukraini (KhKh - pochatok KhKhI st.) : monohrafiia. Ivano-Frankivsk, 2018. $320 \mathrm{~s}$.

Одержано статтю: 3.05 .2018

Прийнято до друку: 17.05.2018

УДК 37: $355.1-058.862^{\prime} 364^{\prime}: 347.633$

DOI: $10.15330 /$ esu. $12.36-41$

\author{
Мар'яна Шуп'яна, \\ аспірант ДВНЗ “Прикарпатський \\ Національний університет імені Василя \\ Стефаника" (м. Івано-Франківськ, Україна) \\ Mariana Shupiana \\ post-graduate student Vasyl Stefanyk Precarpathian \\ national university (Ivano-Frankivsk, Ukraine) \\ mariana020193@gmail.com
}

\section{ГААЗЬКА КОНВЕНЦІЯ: УСИНОВЛЕННЯ ІНОЗЕМЦЯМИ ДІТЕЙ, ЯКІ С ГРОМАДЯНАМИ УКРАЇНИ В РЕАЛІЯХ ТА ПЕРСПЕКТИВАХ}

\section{THE HAGUE CONVENTION: ADOPTION OF CHILDREN WHO ARE THE CITIZENS OF UKRAINE BY FOREIGNERS, REALITIES AND PROSPECTS}

У статті визначено права дитини на сімейне виховання, які порушені в умовах збройного конфлікту, внаслідок якого підвищився ризик зростання сирітства; розглядається проблема усиновления іноземиями дітей, які являються громадянами Украйни; обтрунтовано плюси та мінуси такого усиновлення; проаналізовано Гаазьку Конвениію "Про захист дітей та співробітничтво з питань міждержавного усиновлення”, як альтернативу виріиення нагальних питань щцодо дітей-сиріт; окреслено основні ї иілі та перспективи для дітей означеної категорії.

Ключові слова: антитерористична операчія (АТО), внутрішньо переміщені особи (ВПО), права дитини, виховання, сирітство, усиновлення, Конвенція "Про права дитини", 
Гаазька Конвениія "Про захист дітей та співробітничтво з питань міждержавного усиновлення".

The article defines the child's rights to the family education that are infringed under the conditions of the armed conflict, which increased the risk of the rise of orphanhood; the problem of adoption of children, who are the citizens of Ukraine, by foreigners is considered; advantages and disadvantages of such adoption are grounded; the Hague Convention "On Protection of Children and Cooperation in Respect of Inter-country Adoption" is analysed as an alternative to the solution of urgent problems of orphans; its main goals and prospects for children of the defined category are described.

The main factors of the increase of internal migration are described, which led to the emergence of a new category of subjects of law - internally displaced persons who need urgent legal and social protection; the total number of registered internally displaced persons is specified; from them the number of children is determined in percentage terms; analyzed numerous violations of the rights of the child as a result of armed conflict in the East of Ukraine; describes the influence of internal migration on the development of the personality of a child of preschool age, especially if it is caused by war, as a result of which they become psychologically vulnerable; a brief analysis of the works of scientists from the specified intelligence was carried out; a number of articles of the Constitution of Ukraine on adoption of children are considered, in which the essence of the concept of "adoption" is disclosed, the conditions on which this process is carried out; the benefits of the Hague Convention are outlined; the principles of intercountry adoption are described with maximum consideration of the child's highest interests and observance of his rights and freedoms; describes the need for the adoption of this law for Ukrainian orphans, since joining the Convention introduces a procedure of verification potential adoptive parents, strengthens the control of adoptions abroad, and most importantly - enables the selection of a family for a child, relieves cooperation with countries whose citizens adopts Ukrainian orphans, and as well as implementation of a mechanism for the real protection of the rights of each adopted child.

Key words: anti-terrorist operation (ATO), internally displaced persons (IDPs), child's rights, upbringing, orphanhood, adoption, Convention "On the Rights of the Child", the Hague Convention "On Protection of Children and Cooperation in Respect of Inter-country Adoption".

Постановка проблеми у загальному вигляді. Складна соціально-політична та економічна ситуація, детермінована подіями на сході України, а саме, проведенням Антитерористичної операції, стала основним каталізатором збільшення внутрішньої міграції, що призвело до появи нової категорії суб'єктів права внутрішньо переміщених осіб, які, водночас, потребують нагального правового та соціального захисту. За даними Міністерства соціальної політики, станом на 22 червня 2015 року загальна кількість зареєстрованих ВПО становила 1358000 , приблизно 20000 - з Криму, 743014 виїхали за кордон. Із загальної кількості ВПО 12,6\% - діти [10, с. 43]. Саме діти дошкільного віку є активними свідками ситуацій, що відбуваються в суспільстві і, водночас, особливо вразливою категорією, оскільки їхня емоційна сфера лабільна, що викликає інтенсивність реакцій.

Унаслідок збройного конфлікту на Сході України численних порушень зазнає право дитини на сімейне виховання, адже є людські втрати: діти залишаються без батьків, близьких людей, які за ними доглядали, братів, сестер, родичів, у результаті чого підвищується ризик зростання сирітства [6, с. 280]. Окрім цього, це особливо травмує дитячу психіку, породжує тривожність, страждання, відчуття порожнечі, відчаю, почуття самотності, страху, тривоги, невпевненості в завтрашньому дні, a, інколи, й жорстокість, унаслідок чого вони стають психологічно вразливими. 
Аналіз останніх досліджень та публікацій. Слід зазначити, що окремі питання даної проблематики розглядалися в роботах: Л. Ануфрієвої, І. Городецької, І. Зіміної, Г. Матвєєва, Е. Пєтухової, В. Рясенцева, В. Храбскова та інших вчених.

Виділення невирішених раніше частин загальної проблеми, котрим присвячусться означена стаття. Захист прав дітей i, насамперед, їх найуразливішої категорії - дітей-сиріт та дітей, позбавлених батьківського піклування, $є$ одним із пріоритетних завдань держави, яка повинна створити такі умови, щоб кожна дитинасирота була влаштована на виховання в сім'ю. Однією 3 можливих форм передачі дитини на виховання в сім'ю є міждержавне усиновлення. Забезпечення дієвого механізму міждержавного усиновлення потребує врегулювання питань міжнародноправового співробітництва у цій сфері.

Формулювання цілей статті. Мета статті - аналіз Гаазької Конвенції "Про захист дітей та співробітництво 3 питань міждержавного усиновлення", як альтернативи вирішення нагальних питань щодо дітей-сиріт; визначення основних іiі цілей та перспектив для дітей означеної категорії.

Виклад основного матеріалу досліджень 3 повним обгрунтуванням отриманих наукових результатів. Відповідно до ст. 207 Сімейного Кодексу України (10.01.2002), (надалі - СК України), “усиновлення - це прийняття усиновлювачем у свою сім'ю особи на правах дочки чи сина, що здійснене на підставі рішення суду, крім випадку, передбаченого ст. 282 цього Кодексу" [9].

Усиновлення іноземцем в Україні дитини, яка $є$ громадянином України, здійснюється на загальних підставах, встановлених главою 18 СК України (ст.208242 СК України) [9]. Дитина може бути усиновлена іноземцем, якщо протягом одного року з моменту взяття їі на облік в урядовому органі державного управління 3 усиновлення та захисту прав дитини не виявилося громадянина України, який бажав би ії усиновити або взяти під опіку чи піклування до себе в сім'ю. Усиновлена дитина має право на збереження своєї національної ідентичності відповідно до Конвенції про права дитини та інших міжнародних договорів.

Відповідно до статті 21 Конвенції ООН "Про права дитини” держави -учасниці, які визнають i/чи дозволяють існування системи усиновлення, забезпечують, щоб найкращі інтереси дитини враховувалися в першочерговому порядку, сприяють у необхідних випадках досягненню цілей цієї статті шляхом укладення двосторонніх і багатосторонніх домовленостей або угод та намагаються на цій підставі забезпечити, щоб улаштування дитини в іншій державі здійснювали компетентні органи [3].

На реалізацію вищезгаданої статті було розроблено положення Конвенції “Про захист дітей і співробітництво з питань міжнародного всиновлення", яка була ухвалена 29 травня 1993 року в Гаазі (ії вже ратифікували 89 країн світу), у якій закріплено принципи міждержавного усиновлення 3 максимальним урахуванням найвищих інтересів дитини та дотриманням іiі прав та свобод.

Держави, які підписали цю Конвенцію, визнають:

- дитині для повного та гармонійного розвитку іiі особистості необхідно рости в сімейному оточенні, в атмосфері щастя, любові та розуміння, пам'ятаючи про те, що кожна держава повинна вжити як пріоритетне завдання відповідних заходів, щоб забезпечити залишення дитини на виховання в сім’ї, з якої вона походить;

- міждержавне усиновлення може надати переваги постійної сім’ї дитині, для якої відповідної сім'ї не може бути знайдено в державі її походження; 
- необхідність вжиття заходів для того, щоб забезпечити здійснення міждержавного усиновлення 3 максимальним урахуванням найвищих інтересів дитини та 3 дотриманням iі основних прав, а також, щоб запобігати викраденню, продажу дітей або торгівлі ними [2].

Згідно Статті 1 Гаазької Конвенції "Про захист дітей та співробітництво 3 питань міждержавного усиновлення", іiі цілями $\epsilon$ :

- створення гарантії для забезпечення та здійснення міждержавного усиновлення у найвищих інтересах дитини, а також 3 дотриманням іiі основних прав, визнаних у міжнародному праві;

- створення системи співробітництва між Договірними Державами для забезпечення дотримання таких гарантій і завдяки цьому запобігати викраденню, продажу дітей або торгівлі ними;

- забезпечення визнання в Договірних Державах усиновлень, здійснених згідно із цією Конвенцією [2].

Цей закон $\epsilon$ вкрай необхідним для українських сиріт, адже приєднання до Конвенції запровадить процедуру перевірки потенційних усиновителів, посилить контроль за усиновленими за кордон, а головне - уможливить добір сім'ї для дитини, а не дитини для сім'ї, сприятиме налагодженню співпраці 3 країнами, громадяни яких усиновлюють українських сиріт, а також упровадженню механізму реального захисту прав кожної всиновленої дитини.

Неодноразово Верховна Рада України порушувала законопроект про ратифікацію зазначеної Конвенції, що мав на меті забезпечити гармонізацію процедури усиновлення дітей іноземцями в Україні з процедурами інших держав-учасниць; створити чітку й прозору систему гарантій того, що міждержавне усиновлення здійснюється у найвищих інтересах дитини та 3 дотриманням усіх їі основних прав; окреслити систему співробітництва між Договірними Державами для забезпечення дотримання таких гарантій і таким чином запобігти викраденню, продажу дітей або торгівлі ними, а також запровадити міжнародно-правовий механізм співробітництва у сфері міжнародного усиновлення і забезпечити визнання у Договірних Державах усиновлень, здійснених згідно з цією Конвенцією.

Нещодавно Верховна Рада вкотре відмовилася приєднати Україну до Конвенції "Про захист дітей та співробітництво 3 питань міждержавного усиновлення", пояснюючи це тим, що дітей 3 України зможуть всиновлювати одностатеві пари, а передбачені Конвенцією акредитовані організації будуть використовувати свої повноваження для недобросовісного посередництва $\mathrm{i}$ дітей будуть відправляти не в родини, а в рабство.

Це у свою чергу викликало активні дискусії в широких колах громадськості, які виступили за підтримку даної Конвенції. Особливими прихильниками даної Конвенції є партнерство “Кожній дитині", а також Дитячий фонд ООН (ЮНІСЕФ), які вказували на їі переваги:

- інструменти Гаазької Конвенції дадуть можливість ефективно контролювати та перевіряти умови, в яких живуть і виховуються українські діти, усиновлені в інші країни;

- Конвенція припинить нелегальну діяльність у сфері міжнародного всиновлення;

- ратифікація дасть можливість знати про долю кожної дитини, яка сьогодні усиновлена за кордон;

- відомості про майбутнє всиновлених дітей із країн-реципієнтів до державидонора будуть передаватися через акредитовані агентства; 
- право відстежувати умови проживання усиновлених дітей буде передано місцевим соціальним службам.

Зокрема, партнерство "Кожній дитині" наголошує на тому, що Гаазька Конвенщія пропагує етичні та прозорі процеси усиновлення, виключає прояви недбалості та незаконності у процедурах усиновлення і всебічно захищає права та інтереси усиновленої дитини.

Зазначимо, наразі, відповідно до "Сімейного кодексу" пріоритетне право на усиновлення дитини мають громадяни України. Окрім того, перевага надається подружжю. Дитина може бути усиновлена іноземцем, якщо не виявилося громадянина України, який бажав би її усиновити або взяти на виховання до себе в сім'ю. У кодексі також прописано, що усиновлювачами не можуть бути особи однієї статі. Іноземець може усиновити дитину з України, якщо вона принаймні рік перебуває на обліку в Мінсоцполітики та досягла п'яти років - проте передбачено й випадки, коли це може відбутися раніше.

Важливо ще раз наголосити на тому, що в Конвенції “Про захист дітей та співробітництво 3 питань міждержавного усиновлення" чітко зазначається: міжнародне усиновлення може проводитися лише в останню чергу - тоді, коли дитина не має інших варіантів виховуватися в сім'ї у своїй рідній країні. Про це, зокрема, йдеться у Преамбулі та статті 4 Конвенції.

Сучасні міжнародні стандарти вважають міждержавне усиновлення найкращим варіантом для дітей, які не можуть отримати належної опіки у своїй рідній країні. Звичайно, необхідно робити все для того, щоб українські діти залишались у нашій країні, однак відомі випадки, коли це неможливо.

Отож, загострення конфлікту на Сході України зумовило необхідність удосконалення законодавчого забезпечення захисту прав дітей-сиріт в умовах збройного конфлікту. Шляхом вирішення означеної проблеми могло б бути присднання України до Конвенції, що гармонізувало б процедуру усиновлення дітей іноземцями 3 процедурами інших держав-учасниць, створило б чітку та прозору систему гарантій того, що міждержавне усиновлення здійснюється у найвищих інтересах дитини та 3 дотриманням усіх іiі основних прав. Тому міжнародне усиновлення наразі $\epsilon$ найкращим засобом забезпечення дітей батьками, які будуть не лише любити їх, а й зможуть створити сиротам кращі побутові умови для життя.

Діти - це наше майбутнє! Важливо закликати суспільство об'єднатися і разом вимагати від держави конкретних рішучих дій для захисту прав дітей-сиріт, їх усиновлення до часу вирішення збройного конфлікту.

\section{Література}

1. Бабухіна С. Усиновлення дітей іноземцями: плюси і мінуси / С. Бабухіна // День. - 2003.- № 24. $-8 \mathrm{c}$.

2. Конвенція "Про захист дітей та співробітництво 3 питань міждержавного усиновлення" від 29 травня 1993 року / [Електронний ресурc]. URL: http://search.ligazakon.ua/l_doc2.nsf/link1/ MU93382

3. Конвенції ООН про права дитини від 20 листопада 1989 року / [Електронний ресурc]. URL: $\mathrm{https}: / / \mathrm{www} . u n i c e f . o r g / \mathrm{ukraine} / \mathrm{ukr} /$ convention_small_final

4. Конституція України від 28 червня 1996 року / Відомості Верховної Ради України. - 1996р №30 - C. 141 .

5. Мазур Г.Є. Правові проблеми дітей України в умовах військової агресії / Г.Є. Мазур // Право. - 2015. - №30. - С. $134-139$.

6. Опольська Н. Права дітей, які постраждали внаслідок збройного конфлікту в Україні / Н. Опольська // Право. - 2015 . - №27. - С. 278 - 283. 
7. Про охорону дитинства: Закон України від 26 квітня 2001 року / Відомості Верховної Ради України. -2001. - №30. - С. 142.

8. Сирітству - ні! / Всеукраїнська громадська організація "Магнолія" [Електронний ресурс]. URL: http://magnolia.org.ua-

9. Сімейний кодекс України від 10.01.2002 p. / [Електронний ресурc]. - URL: http://zakon2.rada.gov.ua/laws/ show/2947-14

10. Хаустова О.О., Коваленко Н.В. Актуальні проблеми життя і порушення психічного здоров 'я внутрішньо переміщених осіб / О.О. Хаустова, Н.В. Коваленко // Архів психіатрії. - 2015. № 2 (81). - C. 42- 46 .

\section{References}

1. Babukhin, S. (2003). Ysunovlenn'a ditey inozemtcamu: plysu I minysu [Adoption of children by foreigners: pros and cons]. Day, 24, 8.

2. The Convention on Protection of Children and Cooperation on Intercountry Adoption of May 29, 1993. Retrieved from http://search.ligazakon.ua/1_doc2.nsf/link1/MU93382

3. UN Convention on the Rights of the Child of November 20, 1989. Retrieved from https://www.unicef.org/ukraine/ukr/convention_small_final

4. The Constitution of Ukraine of June 28, 1996. Information from the Verkhovna Rada of Ukraine. 1996, 30, 141.

5. Mazur, G. E. (2015). Pravovi problemu ditey Ykrainu v ymovax viys'kovoi ahresii [Legal problems of children of Ukraine in conditions of military aggression]. Right, 30, $134-139$.

6. Opolskaya, N. (2015). Prava ditey, yaki postrazhdalu vnaslidok zbroynoho konflikty v Ykraini [Rights of Children Affected by Armed Conflict in Ukraine]. Law, 27, 278-283.

7. On the Protection of Childhood: Law of Ukraine dated April 26, 2001. Information from the Verkhovna Rada of Ukraine. 30, 142.

8. Orphanhood - no! All-Ukrainian NGO "Magnolia" Retrieved from http: //magnolia.org.ua

9. The Family Code of Ukraine of January 10, 2002 . Retrieved from http://zakon2.rada.gov.ua/laws/ show / 2947-14

10. Khustova O., Kovalenko N. (2015). Aktyal'ni problemu zhutt'a i poryshenn'a psuxichnoho zdorov'a vnytrishn'o peremischenux osib [Actual problems of life and violation of the mental health of internally displaced persons ] Archive of Psychiatry. 2 (81), 42- 46.

Одержано статтю: 13.03.2018

Прийнято до друку: 27.03.2018 